University of Nebraska - Lincoln

DigitalCommons@University of Nebraska - Lincoln

Faculty Publications from the Harold W. Manter Laboratory of Parasitology

$1-2003$

\title{
Taenia pencein. sp. from the Ringtail, Bassariscus astutus (Carnivora: Procyonidae), in Texas, U.S.A.
}

Robert L. Rausch

University of Washington, rausch@uw.edu

Follow this and additional works at: https://digitalcommons.unl.edu/parasitologyfacpubs

Part of the Parasitology Commons

Rausch, Robert L., "Taenia pencei n. sp. from the Ringtail, Bassariscus astutus (Carnivora: Procyonidae), in Texas, U.S.A." (2003). Faculty Publications from the Harold W. Manter Laboratory of Parasitology. 341. https://digitalcommons.unl.edu/parasitologyfacpubs/341

This Article is brought to you for free and open access by the Parasitology, Harold W. Manter Laboratory of at DigitalCommons@University of Nebraska - Lincoln. It has been accepted for inclusion in Faculty Publications from the Harold W. Manter Laboratory of Parasitology by an authorized administrator of DigitalCommons@University of Nebraska - Lincoln. 


\title{
Taenia pencei n. sp. from the Ringtail, Bassariscus astutus (Carnivora: Procyonidae), in Texas, U.S.A.
}

\author{
ROBERT L. RAusch \\ Department of Pathobiology and Department of Comparative Medicine, Box 357190, \\ University of Washington, Seattle, Washington 98195, U.S.A. (e-mail: rausch@u.washington.edu)
}

ABStract: Taenia pencei n. sp. is described from the ringtail, Bassariscus astutus (Carnivora: Procyonidae), in western Texas, U.S.A., and its metacestode is characterized on the basis of specimens from Peromyscus cf. maniculatus in southern Oregon. Taenia pencei $\mathrm{n}$. sp. apparently occurs exclusively in the ringtail, and it is the first cestode of the genus Taenia known from a member of the family Procyonidae. It is morphologically most similar to species of Taenia from mammals of the family Mustelidae in subclade 2 of the recently constructed phylogeny of that genus. Taenia pencei is distinguished from the nearctic Taenia taxidiensis in the badger Taxidea taxus; from the palaearctic Taenia martis occurring in members of the genus Martes and other mustelids in Europe; from the holarctic Taenia twitchelli in the wolverine Gulo gulo; and from the nominal species of small-hooked cestodes in mustelids (not including Taenia mustelae, in a different subclade), of which all but one have been described from members of the genus Martes. According to the concept presented in this study, those cestodes represent a single, holarctic species, Taenia cf. intermedia, synonyms of which, on grounds of priority, are Taenia sibirica and Taenia skrjabini, both described from Martes zibellina in Eurasia, and Tae. martis americana from Martes spp. in North America. Taenia melesi, from the Eurasian badger Meles meles, remains species inquirenda. Taenia pencei $\mathrm{n}$. sp. is distinguished from all the aforementioned species by form and dimensions of rostellar hooks and by the arrangement and characteristics of genital organs. The holarctic occurrence of Taenia cf. intermedia appears to be a consequence of dispersals of mammals via Beringia during the late Pleistocene.

KEY WORDS: Cestoda, Taeniidae, Taenia pencei n. sp., Taenia spp. from Mustelidae, ringtail, Bassariscus astutus, Procyonidae.

Pence and Willis (1978) reported the occurrence of a cestode of the genus Taenia in ringtails, Bassariscus astutus (Lichtenstein, 1830), trapped in 5 counties of western Texas. Their finding was the first record of a member of the genus Taenia from the family Procyonidae. They noted that the cestode was most similar to taeniids from mustelids. The cestode was tentatively identified as Taenia martis (Zeder, 1803), without allocation to subspecies because it was not morphologically compatible either with Tae. m. martis (Zeder, 1803), occurring mainly in mustelids of the genus Martes in Europe, or with Tae. m. americana Wahl, 1967, occurring in mustelids of the same genus in North America.

In view of the uncertainty about the identity of that cestode, Dr. Danny B. Pence kindly made specimens available for further study. They represent an unknown species, which is described in this study. In addition, the cestode that was previously named Tae. m. americana is shown to be an independent species, probably identical with taxa reported from mustelids of the genus Martes in Eurasia; in the present study, it is designated Taenia ef. intermedia Rudolphi, 1809.
In this study only those species of Taenia that are from carnivores of the family Mustelidae in subclade 2 of the phylogenetic arrangement by Hoberg et al. (2000) are considered. Two additional species in that subclade occur in members of the family Canidae, but morphologically they differ markedly from those in mustelids in both the strobilar stage and the metacestode.

\section{MATERIALS AND METHODS}

The cestode from B. astutus was represented by portions of 10 specimens that were stained with celestine blue and mounted permanently on slides, each slide containing a rostellum and a series of mature proglottids and of early gravid proglottids. In all cases, pressure had been applied to the cover glass to cause hooks, if any, to lie flat. The material consisted of 93 mature proglottids, 43 early gravid proglottids, 5 large rostellar hooks, and 24 small hooks. The metacestodes identified as that of the same species provided further data including numbers of rostellar hooks.

Relative lengths of blade and handle of hooks were measured from a vertical line parallel with the posterior margin of the guard. Ares of blades of some hooks were compared by the method of Feduccia (1993). Illustrations of hooks were prepared from enlarged photographs taken at $\mathrm{x} 400$.

Of the cestodes studied (all mounted permanently), specimens of Tae. m. martis were stained with lactic 
acid carmine solution, whereas others were stained with acetic carmine. Species compared were as follows-Taenia martis martis: 2 complete specimens and rostellar hooks only from 2, from Martes foina (Erxleben, 1777), southern Germany, leg. B. LoosFrank. Taenia martis americana, herein designated Taenia cf. intermedia Rudolphi, 1809, all from Martes americana (Turton, 1806): 1 from Mayo Lake, Yukon Territory, Canada, leg. P. Youngman; 2, Nos. 73275 and 80019 , United States National Parasite Collection, Beltsville, Maryland, U.S.A., and 1, Washington State, leg. E. P. Hoberg; 3 from Alaska, leg. RLR; and metacestodes from a vole, Microtus xanthognathus (Leach, 1815), northern Yukon Territory, leg. P. Youngman. Taenia taxidiensis Skinker, 1935, from the nearctic badger, Taxidea taxus (Schreber, 1778): 2 from Malheur County, Oregon, leg. C. Maser; 4 from Madison County, Montana, leg. J. Rozdilsky; 2 from Dane and Sauk Counties, Wisconsin, leg. RLR. Taenia twitchelli Schwartz, 1924, from the wolverine, Gulo gulo (Linnaeus, 1758): 10 from various localities in Alaska, leg. RLR. Metacestode of Taenia pencei n. sp.: 3 individuals from Peromyscus cf. maniculatus (Wagner, 1845), $6 \mathrm{~km}$ south of Bandon, Curry County, Oregon, leg. C. Maser.

All measurements reported in this study are in micrometers unless otherwise stated.

\section{Taenia pencei n. sp. Rausch, 2003 Adult (Figs. 1-4)}

\section{Description}

Length of strobila not precisely determined but less than $100 \mathrm{~mm}$ (Pence, personal communication). Margins of strobila slightly serrate. Mature proglottids 0.88 to $1.04 \mathrm{~mm}$ wide at anterior margin, 1.05 to $1.4 \mathrm{~mm}$ at posterior margin, and 0.9 to $1.0 \mathrm{~mm}$ in length; mean length of mature proglottids $74 \%$ of mean width at posterior margin. Complete scoleces not available. Rostellum armed with 34 hooks in 2 rows (based on metacestode). Large hooks 166 to 176 in length (average $=169$ ), blade $46 \%-54 \%$ (average $49 \%$ ) of length; small hooks 138 to 153 (average $=139$ ), blade $38 \%-45 \%$ (average $42 \%$ ); arc of blade of large hook $99^{\circ}$. In general form, rostellar hooks typical of those of most Taenia spp. in mustelids (excluding Tae. taxidiensis). Genital pores irregularly alternate, situated anteriorly on lateral margin of proglottid, $27 \%$ $31 \%$ (average $=29 \%$ ) posterior to its anterior margin. Genital papilla little developed. Opening of genital atrium 70 to 90 in diameter. Ventral longitudinal excretory canals 36 to 73 in diameter; transverse canals 15 to 51 ; dorsal canal 10 to 12 . Genital ducts passing either dorsally or ventrally across excretory canals (e.g., in sequence of 8 mature proglottids: 5 dorsal, 3 ven- tral; in 1 proglottid, male genital duct was dorsal to ventral canal, and female genital duct was ventral). Cirrus sac clavate, 122 to 244 in length (average $21=188$ ), 52 to 73 (average $21=61$ ) in maximal diameter at about $25 \%$ of length from proximal end. Cirrus sac opening anterior to vagina into genital atrium and in mature segments extending 49 to 90 beyond medial margin of ventral excretory canal. Wall of cirrus sac 10 13 in thickness; extruded cirrus 109 to 132 in length, diameter at base 27 to 36 , and 15 at distal end. Vas deferens with numerous loops medial to proximal end of cirrus sac, extending posteromediad to slightly beyond midline of proglottid, there turning posteriad. Testes subspherical, 34 to 48 in greater diameter by 32 to 43 (average $45 \times 37$ ); arranged in 2 major layers over most of field between longitudinal excretory canals. In 7 mature segments, number of testes ranging from 261 to 330 (average $=282$ ). Testes confluent across anterior of proglottid, with usually at least 1 row extending across posterior margin, posterior to vitelline gland. Testes overlapping margins of ovarian lobes dorsally and extending between medial margins of ovarian lobes and vitelline gland. Vagina enlarging distally, opening posterior to orifice of male duct and extending mediad parallel with vas deferens to lateral margin of testicular field, there turning posteromediad and extending to seminal receptacle situated posteriorly at midline. Vagina 50 to 60 in diameter near genital atrium, thereafter often narrowing to 24 to 30 ; lumen of vagina lined with minute, cilia-like structures, except in narrow, straight portion just anterior to seminal receptacle. Ovary consisting of 2 lobes of which aporal lobe is larger. Aporal lobe 190 to 450 in length by 110 to 250 (average $292 \times 189$ ); poral lobe 160 to 310 in length by 100 to 210 (average $256 \times 163$ ). Long axes of lobes somewhat convergent anteriad toward midline. Vitelline gland lobulate, situated on midline posterior to ovarian lobes, 105 to 180 in length by 146 to 255 (average $149 \times 204$ ). Uterus arising dorsally as tubular structure on midline, extending to anterior margin of mature proglottid. Early gravid proglottids 2.0 to $4.5 \mathrm{~mm}$ in length (average 3.2), with maximal width 1.4 to $1.8 \mathrm{~mm}$ (average 1.6) at posterior margin or occasionally near middle. Early gravid uterus filling area between longitudinal excretory canals; lateral uterine branches little developed. Immature eggs, 20 to 26 in greater diameter, consisting of oncosphere en- 
closed by embryonic membrane. Oncosphere 13 to 14 in length by 8 to 10 .

\section{Taxonomic summary}

Type host: Ringtail, Bassariscus astutus (Lichtenstein, 1830).

Type locality: Jeff Davis County, Texas, U.S.A.

Site of infection: Small intestine.

Type specimens: Holotype, United States National Parasite Collection, Beltsville, Maryland, USNPC No. 92283; Paratypes (2): United States National Parasite Collection, USNPC No. 92284; Paratypes (2): Harold W. Monter Laboratory, University of Nebraska State Museum, Lincoln, Nebraska, HWML 16730, 16731.

Etymology: The cestode is named in honor of Danny B. Pence, who has contributed significantly to the knowledge of the helminths of carnivores.

\section{Metacestode (Figs. 5, 6)}

\section{Description}

Metacestode (3 studied) consisting of subspherical vesicle, 4 to $6 \mathrm{~mm}$ in greater diameter, each with 5 pseudosegmented forebodies projecting from vesicular surface (forebodies 1.2 to $2 \mathrm{~mm}$ in length). Scoleces invaginated, near distal end of forebodies, 637 to 860 in diameter; suckers 200 to 300 in diameter. Rostellum with 34 hooks in 2 rows, forming circle 280 to 310 in diameter en face. In each metacestode, rostellar hooks differing somewhat in size, indicating asynchronous development. Large hooks 158 to 171 in length (average 165), blade 47\%$50 \%$ (average $45.5 \%$ ) of length; small hooks 132 to 144 (average 140), blade $42 \%-55 \%$ (average $47.5 \%$ ); arc of blade of large hook $96^{\circ}$.

\section{Taxonomic summary}

Type intermediate host: Deer mouse, Peromyscus cf. maniculatus (Wagner, 1845).

Type locality: Six kilometers south of Bandon, Coos County, Oregon, U.S.A.

Site of infection: Skeletal musculature, dorsal, between scapulae and in axial areas.

Voucher specimens: United States National Parasite Collection, Beltsville, Maryland, U.S.A. USNPC No. 92285 (2 specimens).

\section{Remarks}

Taxonomic and nomenclatural status: To provide a basis for defining the differential characters of Tae. pencei, the synonymies, host occurrence, and geographic ranges of Taenia spp. in mammals of the family Mustelidae (excluding Taenia mustelae Gmelin, 1790) are reviewed. Six nominal taxa have been recognized in Eurasia and 3 in North America. The former consist of Tae. martis, Tae. intermedia Rudolphi, 1809 , Tae. twitchelli Schwartz, 1924; Tae. sibirica Dubnitskii, 1952; Tae. skrjabini Romanov, 1952; and Tae. melesi Petrov et Sadykhov, 1956. The taxa from North America are: Tae. twitchelli; Tae. taxidiensis; and Tae. m. americana. In addition, cestodes, apparently of an undescribed species of Taenia, have been found once, in a marten, M. americana, in Alaska (under investigation).

Uncertainties about the identity of cestodes occurring primarily in carnivores of the genus Martes have prevailed for about 2 centuries as a result of the inadequacies of original descriptions and, after about 1950, of mistaken synonymies. The cestode at present designated Tae. $m$. martis, characterized in part by its large rostellar hooks, occurs commonly in martens, $M$. foina and Martes martes, and occasionally or rarely in mustelids of other species in Europe. At northern latitudes, the range of $M$. foina extends eastward to the Caucasus and that of $M$. martes to the Ural Mountains (Stubbe, 1993), but Tae. m. martis evidently has not been reliably identified beyond eastern Europe. The record given by Loos-Frank (1994) (citing Shuteev, 1977) of its metacestode from a muskrat, Ondatra zibethicus (Linnaeus, 1766), in the region of the upper $\mathrm{Ob}$ ' River is in error; on the upper Ob', Shuteev (1977) obtained only the metacestode of Echinococcus multilocularis Leuckart, 1863. The distributional records of Tae. $m$. martis elsewhere within the limits of the former Soviet Union (Kozlov, 1977) involved mistaken synonyms. Small rodents of the genera Apodemus and Clethrionomys often serve as intermediate hosts, but rodents of various other species become infected. Again, because of uncertain synonymies, records of the metacestode of Tae. m. martis are unreliable (Ryzhikov et al., 1978).

Because Halysis martis Zeder, 1803 (=Tae. martis) was distinguished on the basis of its oc- 
currence in the intestine of "mustela martis" (sic) by Zeder (1803, p. 372), its identity has been questioned (see Abuladze, 1964, for discussion). For a time it was designated Tae. intermedia (Joyeux and Baer, 1934, 1936; Abuladze, 1964; Prokopič, 1965; Schmidt, 1986; and others), although Sprehn (1959) applied the name Tae. martis with adequate characterization. Much of the uncertainty arose after Thienemann (1906) restudied Rudolphi's material of Taenia spp. from mustelids in the collection of the Berlin Zoological Museum. He found that vial no. 3, labeled "Taenia intermedia," from Mustela foina ( $=$ M. foina), contained a single cestode, $98 \mathrm{~mm}$ in length, with 131 proglottids, but details of the reproductive organs were obscured by calcareous corpuscles. Most important, however, was the presence of some ("einige") rostellar hooks. Referring to the measurements of a large hook ("Die Massen eines grossen Hakens ..."), Thienemann (1906) reported a length of $0.145 \mathrm{~mm}$ and remarked that all dimensions corresponded to those given for Tae. intermedia by Leuckart (1856). The 7-8 cestodes in vial no. 4 were dried; hence only the dimensions of the embryophores could be determined. Thienemann (1906) considered the specimens in vial no. 4 to have been the types of Tae. intermedia.

Joyeux and Baer (1934) studied cestodes that they designated Tae. intermedia from M. foina from the vicinity of Nancy, France. Their specimens were contracted, and some details were not discernible. They determined that the scolex had a double row of rostellar hooks, 34 in total, of which the larger measured 210-220 in length and the smaller 150-160. The cirrus sac measured $210-230$ by $70-80$. The gravid uterus had 10-13 lateral branches. They noted the significant differences in comparison with hooks of Tae. hydatigena Pallas, 1766, and remarked that martens could hardly become infected by metacestodes in ruminants. Referring to Thienemann's work (1906), they believed that he had measured only a small hook of Tae. intermedia. However, that Thienemann's examination of Rudolphi's cestodes was thorough cannot be doubted, and he certainly would have distinguished large and small hooks. The characteristics of both Tae. intermedia and Tae. hydatigena were later more adequately defined by Joyeux and Baer (1936). Freeman (1956) considered the work of Joyeux and Baer $(1934,1936)$, and not- ing the large size of rostellar hooks they reported for Tae. intermedia and noting as well that Dubnitskii (1952) had listed Tae. hydatigena as occurring in mustelids in Eurasia, he suggested that Joyeux and Baer had studied Tae. hydatigena rather than Tae. intermedia. It is improbable that Joyeux and Baer could have misidentified a common and well-known helminth in view of their knowledge of the Cestoda; as well, they had discussed Tae. hydatigena, whose cycle typically involves large carnivores and ruminants. Kozlov (1977) also included Tae. hydatigena in his list of cestodes of the stone marten, but its occurrence in mustelids must be very rare.

In his study, Freeman (1956) identified as Tae. martis an immature cestode from the nearctic marten, M. americana, from Ontario, Cana$\mathrm{da}$, on the basis of the form and dimensions of the rostellar hooks, of which large and small measured 146 and 133, respectively. He was aware of the similar hook-dimensions of Tae. sibirica (large 150-153, small 128-130) and of Tae. skrjabini (153-155 and 120-129). Sizes of hooks of those 2 cestodes (see below) from sables, Martes zibellina (Linnaeus, 1758), are much like those of Freeman's specimen. Relying on the similarities in the size and form of rostellar hooks, Freeman (1956) placed Tae. intermedia, Tae. sibirica, and Tae. skrjabini in synonymy with Tae. martis, notwithstanding the much larger dimensions of hooks reported for Tae. martis in Europe (cf. Joyeux and Baer, 1934, 1936). Freeman (1956, footnote) identified small, monocephalic cysticerci from the pleural cavities of Clethrionomys gapperi (Vigors, 1830) as the metacestode of Tae. martis on the basis of characteristics of the hooks.

Wahl (1967), who studied cestodes having large rostellar hooks from M. foina in the val de l'Allondon, Switzerland, as well as Freeman's specimen from $M$. americana, noted (p. 166) that the large hooks of the cestode from Canada coincided in size and form with those of Tae. sibirica and Tae. skrjabini. On grounds of priority, over Romanov's (1952) description, the latter had been placed in synonymy with Tae. sibirica by Abuladze (1964), who suggested that Freeman's cestode represented a North American record of Tae. sibirica. Wahl (1967) did not identify the cestode from $M$. americana as Tae. sibirica but proposed the designation Tae. $m$. 
americana for the nearctic cestode. The nominate species thereby became bitypic.

Taenia sibirica was described from the "Barguzinsk sable" ( $=$ M. zibellina princeps Birula, 1916) in the Barguzinsk region east of Lake Baikal (Geptner et al., 1967). Taenia skrjabini also was described from M. zibellina, from the Krasnoiarsk Krai. Taenia sibirica has been reported from sables from various localities in Siberia. The cestode now designated Tae. m. americana is common in martens in North America. Cestodes apparently of that species from 25 of 162 fishers, Martes pennanti (Erxleben, 1777), in Manitoba were identified as Tae. sibirica by Dick and Leonard (1979), but cestodes from 16 of 139 martens also in Manitoba were identified as Taenia cf. martis martis by Poole et al. (1983).

Concerning the recognition of subspecies of Tae. martis, Verster (1969) accepted Freeman's (1956) concept along with that of Wahl (1967). Verster listed Tae. intermedia, Tae. skrjabini, and Tae. sibirica as synonyms of Tae. martis sensu Zeder, 1803; Tae. intermedia as a synonym of Tae. m. martis; and Tae. sibirica and Tae. skrjabini as synonyms of Tae. m. americana sensu Wahl, 1967. She did not mention the striking dissimilarity in form of the respective metacestodes. Loos-Frank (1994) also retained the subspecific designations (i.e., the subspecies martis and americana) but stated (p. 155) that "... there are morphological differences which, together with the different size and shape of the hooks suggest both to be true species." LoosFrank also studied Tae. sibirica from M. foina in Germany and noted that the rostellar hooks of Tae. sibirica, Tae. m. americana, and Tae. melesi never overlapped those of Tae. m. martis in size, but the available material was considered to be insufficient to determine the relationship of Tae. sibirica and Tae. m. americana.

Differences in the metacestodes of Tae. $m$. martis and Tae. $m$. americana alone clearly show that they represent independent species. That of subspecies martis, first identified by Schmidt (1961) (designated by him as Tae. intermedia), is a large, monocephalic, fimbriated structure (Schaerer, 1987; Loos-Frank, 1994). Loos-Frank found that specimens from the pleural cavities of small rodents (Apodemus spp. and Clethrionomys glareolus (Schreber, 1780)) attained a length of $80 \mathrm{~mm}$, with a mean of 34 $\mathrm{mm}$; mean length of those from the peritoneal cavity was $63 \mathrm{~mm}$. Metacestodes in muskrats were larger (maximal recorded length $180 \mathrm{~mm}$ ). The metacestode of Tae. $m$. americana is a small, monocephalic cysticercus (Freeman, 1956; Rausch, 1977). A metacestode from the "lungs" (=pleural cavities?) of a red-backed vole, C. glareolus, in Austria was identified as that of Tae. sibirica by Pfaller and Tenora (1972) on the basis of the rostellar hooks; a detailed description was not given.

The morphological characters of Tae. $m$. americana (cf. Rausch, 1977) suffice to establish its specific independence from Tae. martis sensu Zeder (1803) and to indicate its affinity with Tae. intermedia. As characterized by Joyeux and Baer (1934, 1936), Wahl (1967), and LoosFrank (1994), Tae. martis is the common species found in martens in Europe. The cestode now designated Tae. sibirica occurs in sables and martens over most of northern Eurasia, from Europe to northeastern Siberia. The size $(0.145$ $\mathrm{mm}$ ) of the large hook reported by Thienemann (1906) places Tae. intermedia with the smallhooked species, with which it agrees also in relatively small size of strobila. On grounds of priority, Tae. sibirica Dubnitskii, 1952 would become a synonym of Tae. intermedia Rudolphi, 1809. Thienemann's data (1906) concerning Tae. intermedia are considered to be accurate; if he had measured a small rostellar hook the cestode even so could not have been Tae. martis, whose small hooks range from 167 to $198 \mu \mathrm{m}$, with a mean (for 70 hooks) of $181 \mu \mathrm{m}$ (LoosFrank, 1994). In the present study, because Eurasian specimens designated Tae. sibirica have not been available for direct comparison with the cestode from nearctic martens, the question of conspecificity could not be determined with certainty. Thus, provisionally, the North American species (host: M. americana) is here designated Taenia cf. intermedia.

With respect to Taenia cf. intermedia in the Nearctic, the distributional history of its usual host, $M$. americana, indicates a late Pleistocene dispersal eastward via Beringia (Kurtén and Anderson, 1980). An earlier invasion during Wisconsin Time led to its spread into the southeastern region of North America after which it became isolated by the continental ice. A later dispersal into western North America then occurred. Consequently, the populations of $M$. americana consist of 2 morphologically distinct groups of subspecies (Clark et al., 1987). The 
western subspecies (the caurina-group) are in cranial and dental characters more similar to the Eurasian $M$. zibellina than are the eastern subspecies (the americana-group) (Kurtén and Anderson, 1980). Taenia cf. intermedia conceivably reached the Nearctic with either or both invasions of martens.

The status of Tae. melesi, described from a Eurasian badger, Meles meles (Linnaeus, 1758), in the former Azerbaidzhan SSR, in Russia, remains uncertain. The lengths of the rostellar hooks (148-154 and 130-136) are similar to those of the other small-hooked cestodes in mustelids. According to the original description, reproduced in Abuladze (1964), Tae. melesi had a much longer strobila, up to $162 \mathrm{~mm}$, and was quite wide $(4-4.6 \mathrm{~mm})$; numbers of testes ranged from 120 to 150 , with none situated posterior to the ovarian lobes and vitelline gland. The metacestode is unknown. Verster (1969) listed it as species inquirenda but stated that it appeared to be identical to Tae. m. americana. It was included, along with Tae. intermedia, Tae. sibirica, and Tae. skrjabini, as a synonym of Tae. martis by Kozlov (1977). However, Tae. melesi is evidently morphologically distinctive; it is perhaps a host-specific cestode of the badger.

The holarctic species Tae. twitchelli occurs in the wolverine, G. gulo. It was thought to be limited to the Nearctic until Domnich and Obushenkov (1983) identified it in 7 of 8 wolverines from the vicinity of Markovo and in 14 of 16 in the basin of the Omolon River, both in northeastern Siberia. It is the most common helminth in wolverines in North America, found in 102 of 134 examined in Alaska (Rausch, 1977). There, the metacestode developed in the pleural cavities of the intermediate hosts, usually marmots, Marmota spp. (cf. Rausch, 1959, 1977). Cestodes reported from wolverines in Siberia before the findings of Domnich and Obushenkov (1983), identified as Tae. martis, were possibly Tae. twitchelli (cf. Loos-Frank, 1994). Because the rostellar hooks of Tae. twitchelli are very similar to those of Tae. martis, the 2 taxa were believed to be conspecific by Wahl (1967) and Prokopič (1970). That Tae. twitchelli is an independent species has been confirmed by Verster (1969) and Loos-Frank (1994), in part on the basis of the unusual form of its metacestode (cf. Rausch, 1977, fig. 1). The metacestode resembles only that of Tae. endothoracica Kirshen- blat, 1948 (cf. Shul'ts and Gvozdev, 1970, fig. 117), from which it differs not only in size and form of the rostellar hooks but also in the process of morphogenesis (Rausch, 1959; Hulínská, 1975). The metacestode of Tae. endothoracica occurs in the pleural cavities of gerbils of various species; foxes (Vulpes spp.) are the final host.

Taenia taxidiensis (syn. Fossor angertrudae Honess, 1937, and Monordotaenia taxidiensis (Little, 1967)) occurs only in the nearctic badger, Tax. taxus. The metacestode, a simple cysticercus, was first obtained experimentally by Pederson and Leiby (1969) in ground squirrels, Spermophilus spp. (designated Citellus spp. in Europe), which are the major prey of the badger. Naturally infected ground squirrels were reported by Jenkins and Grundmann (1973), in Utah, and by McGee (1980) in Saskatchewan. Taenia taxidiensis is distinguished in part by the presence of a single row of rostellar hooks of unique form.

Comparisons with taxonomically allied taxa: Taenia pencei is distinguished from the following species by direct comparisons:

From Tae. martis (southwestern Germany), it differs in lengths of rostellar hooks (cf. Fig. 4), in size of strobila, and in dimensions and proportions of proglottids. The cirrus sac of Tae. pencei is relatively much longer, extending well beyond the medial margin of the ventral longitudinal excretory canal. Testes are arranged in 2-3 layers and closely apposed. The ovarian lobes are much smaller and of different shape. The vitelline gland is much smaller. The metacestode is diagnostic. Taenia pencei is known only from B. astutus. (Tae. martis: large hooks, avg 227, small hooks, 181; strobila up to 315 $\mathrm{mm}$ in length; cirrus sac extending mediad to or just beyond lateral margin of ventral canal; testes widely spaced, usually in a single layer; ovarian lobes fan-shaped, lobules usually well developed laterally; vitelline gland, average length 134 , width 452 . The metacestode is a monocephalic, fimbriated cysticercus.)

From nearctic specimens of Taenia $\mathrm{cf}$. intermedia, it differs in having larger rostellar hooks (Fig. 4), and hooks are more numerous. The strobila is more robust and wider. The cirrus sac is larger, extending well beyond the medial margin of the ventral longitudinal excretory canal. Testes are more numerous. Ovarian lobes and vitelline gland are not closely apposed. The 


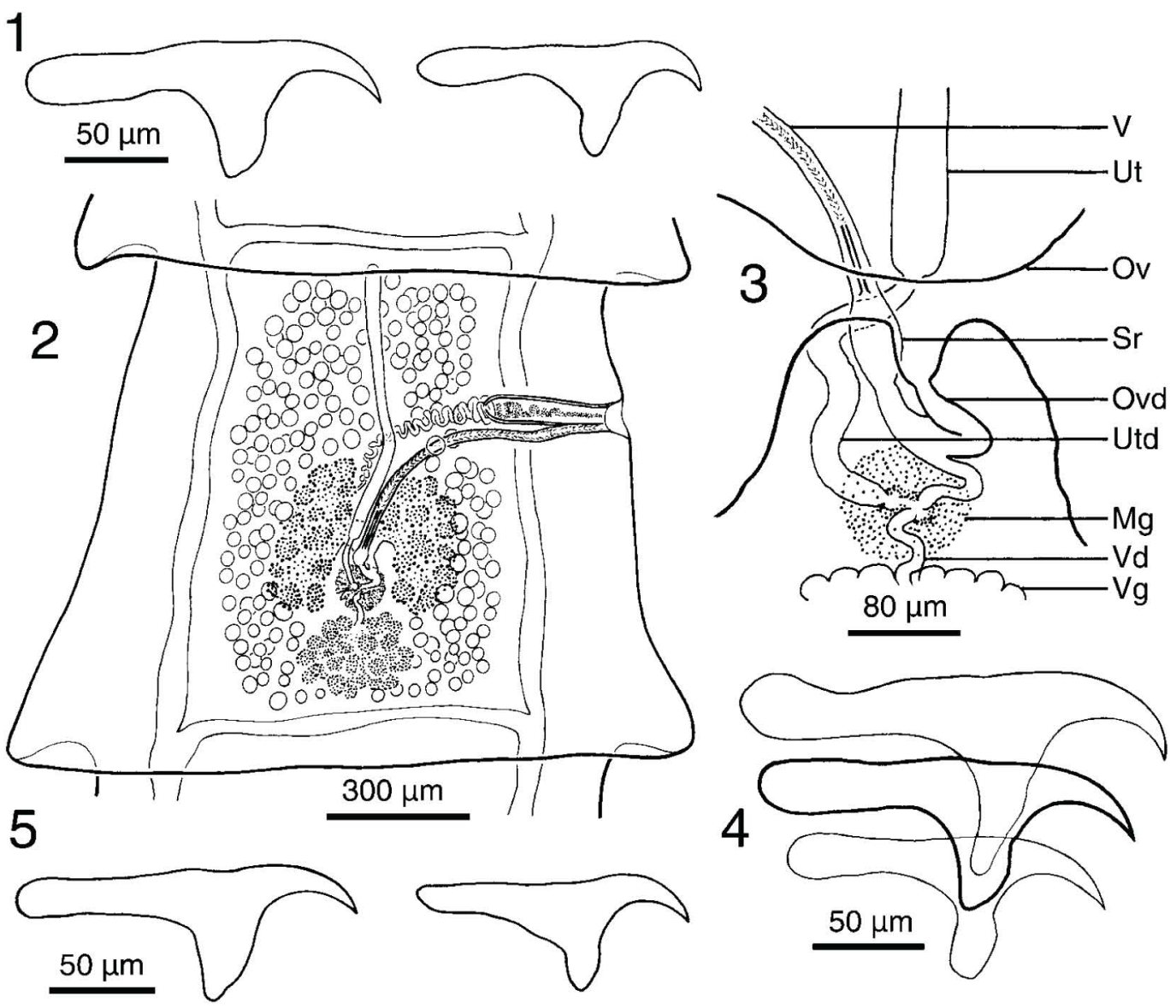

Figures 1-5. Taenia pencei sp. n. 1. Rostellar hooks. 2. Mature segment, dorsal view. 3. Details of female genital ducts, ventral view. 4. Comparison of some large rostellar hooks: Taenia martis (and Taenia twitchelli) (top); Taenia pencei (middle); and Taenia cf. intermedia, from nearctic marten (bottom). 5. Rostellar hooks of Taenia pencei, metacestode. V, vagina; Ut, uterus; Ov, ovary; Sr, seminal receptacle; Ovd, oviduct; Utd, uterine duct; Mg, Mehlis' gland; Vd, vitelline duct; Vg, vitelline gland.

metacestode is distinctive. (Nearctic Taenia cf. intermedia: large hooks, average 143, small hooks, 123; usually 28 hooks; maximal strobilar width 0.832 to $1.2 \mathrm{~mm}$; cirrus sac, average 149 $\times 60$, not reaching medial margin of ventral canal; testes, average 110 per proglottid, in 1 layer. The metacestode is a simple, monocephalic cysticercus.) Taenia cf. intermedia occurs in Martes spp. in North America and in mustelids of various species in Eurasia.

From Tae. twitchelli, it is immediately distinguished by its smaller rostellar hooks. The strobila is smaller, with margins less serrate. Distribution of the testes is more extensive. The cirrus sac is less slender and relatively longer. The metacestode is diagnostic. (Tae. twitchelli: hooks closely resemble those of Tae. martis; large hooks 200-212, small hooks 156-168; mature segments are trapezoidal; testes usually are confined to lateral fields and not confluent anteriorly; cirrus sac does not reach the medial margin of the ventral canal. The metacestode consists of numerous, elongate, monocephalic vesicles attached to a vestigial bladder.)

From Tae. taxidiensis, Tae. pencei is distinguished by its much smaller strobila; in having 2 rows of "mustelid-type" rostellar hooks; and in arrangement and proportions of the genital organs. The metacestode is diagnostic. (Tae. taxidiensis: strobila up to $480 \mathrm{~mm}$ in length. Scolex has a single row of hooks of unique shape. The metacestode is a simple, monocephalic cysticercus.) Taenia taxidiensis is a nearctic species in the North American badger. 


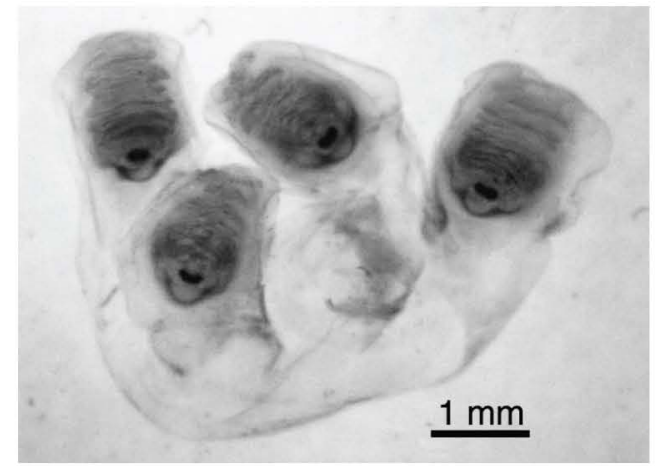

Figure 6. Taenia pencei sp. n., metacestode from Peromyscus cf. maniculatus. (One scolex was removed for study of rostellar hooks.)

\section{DISCUSSION}

Taenia pencei was found in $3(20 \%)$ of the 15 ringtails examined for helminths in Texas (Pence and Willis, 1978). Its prevalence suggests that it is host-specific in that carnivore. Another procyonid, the raccoon, Procyon lotor (Linnaeus, 1758), has an extensive distribution in North America. Its helminth fauna, relatively well known, so far includes no species of Taenia. That none of 10 cestodes from the ringtail had fully developed eggs seemed unusual, but a similar condition was noted in Tae. taxidiensis, of which only 1 of 28 cestodes obtained from 3 badgers (in Wisconsin) had gravid segments (Rausch, 1947).

My identification of the metacestode of Tae. pencei was based, first, on characteristics of the rostellar hooks (dimensions of the hooks varied slightly in each of the 3 metacestodes examined). Hooks of the scolex found to be the most advanced in development (large hooks, 168 to 171 in length; small hooks, 137 to 144) were similar in size to those of the strobilar stage. The arcs of the blades of large hooks of the strobilar stage and of the metacestode also were nearly identical, 99 and $96^{\circ}$, respectively. Other evidence as well supports the identification of the metacestode. First, it differs morphologically (Fig. 6) from all other known metacestodes of Taenia spp. Second, it is evidently unique in locus in the host - in skeletal muscle of a small mammal (Cricetidae). Among others that occur in arvicolids, the proliferative metacestode of Tae. crassiceps (Zeder, 1800) typically produces aggregations subcutaneously or in the pleural and in the peritoneal cavities of its hosts. The metacestode of Tae. taxidiensis occurs in skeletal and smooth muscles of ground squirrels, family Sciuridae. Finally, there is a distributional component. The deer mouse infected by the metacestode was collected in southern Oregon, within the geographic range of the ringtail. (No cestode was present in 2 ringtails that I examined from the same area.)

Like other procyonids, the ringtail is omnivorous. Rodents (with carrion) reportedly make up about $24 \%$ of its diet (Davis, 1978). The infected deer mouse was identified as $P$. maniculatus, but its standard measurements somewhat exceeded those of that species. According to Hall (1981), $P$. maniculatus does not have an extensive range in Texas, occurring in the far southwest and in the east-central regions, but 2 other species of Peromyscus occur more widely in the state; 2 subspecies of Peromyscus leucopus (Rafinesque, 1818) have extensive ranges, and Peromyscus truei (Shufeldt, 1885) is present in the north. That other indigenous rodents may serve as intermediate host of Tae. pencei is conceivable and could be determined experimentally.

\section{ACKNOWLEDGMENTS}

Comparative material used in this study was kindly made available by Eric P. Hoberg, Brigitte Loos-Frank, Chris Maser, John Rozdilsky, and Philip Youngman. Eric P. Hoberg also provided literature and useful comments. Virginia R. Rausch prepared the figures and assisted additionally with the work. I express sincere thanks for those contributions.

\section{LITERATURE CITED}

Abuladze, K. I. 1964. Teniaty-lentochnye gel'minty zhivotnykh i cheloveka i vyzyvaemye zabolevaniia. Osnovy Tsestodologii. Vol. 4. K. I. Skriabin, ed. Akademiia Nauk SSSR, Moskva, U.S.S.R. 530 pp.

Clark, T. W., E. Anderson, C. Douglas, and M. Strickland. 1987. Martes americana. Mammalian Species No. 289, American Society of Mammalogists. 8 pp.

Davis, W. B. 1978. The mammals of Texas. Bulletin No. 41, Texas Parks and Wildlife Department, Austin, Texas, U.S.A. 294 pp.

Dick, T. A., and R. D. Leonard. 1979. Helminth parasites of fisher Martes pennanti (Erxleben) from Manitoba, Canada. Journal of Wildlife Diseases 15:409-412.

Domnich, I. F., and I. N. Obushenkov. 1983. Gel'mintofauna khishchnykh mlekopitaiushchikh severovostochnoi Azii. Institut Biologicheskikh Problem Severa, Dal'nevostochnyi Nauchnyi 
Tsentr, Akademiia Nauk SSSR, Magadan, U.S.S.R. 17 pp.

Dubnitskii, A. A. 1952. Novaia tsestoda iz kishechnika barguzinskikh sobolei. Karakulevodstvo i Zverovodstvo, No. 4:79.

Feduccia, A. 1993. Evidence from claw geometry indicating arboreal habits of Archaeopteryx. Science 259:790-793.

Freeman, R. S. 1956. Life history studies on Taenia mustelae Gmelin, 1790 and the taxonomy of certain taenioid cestodes from Mustelidae. Canadian Journal of Zoology 34:219-242.

Geptner, V. G., N. P. Naumov, P. B. Iurgenson, A. A. Sludskii, A. F. Chirkova, and A. G. Bannikov. 1967. Mlekopitaiushchie Sovetskogo Soiuza. Vol. 2, Part 1. Morskie korovy i khishchnye. V. G. Geptner and N. P. Naumov, eds. Vysshaia Shkola, Moskva, U.S.S.R. 1004 pp.

Hall, E. R. 1981. The mammals of North America, 2nd ed., Vol. 2. John Wiley and Sons, New York, New York, U.S.A. $1181+90$ pp.

Hoberg, E. P., A. Jones, R. L. Rausch, K. S. Eom, and S. L. Gardner. 2000. A phylogenetic hypothesis for species of the genus Taenia (Eucestoda:Taeniidae). Journal of Parasitology 86 : 89-98.

Hulínská, D. 1975. Morphogenesis of the larval stages of Multiceps endothoracicus. Part 1. Zoologischer Anzeiger 195:201-219.

Jenkins, E.-R., and A. W. Grundmann. 1973. The parasitology of the ground squirrels of western Utah. Proceedings of the Helminthological Society of Washington 40:78-86.

Joyeux, Ch., and J.-G. Baer. 1934. Sur quelques cestodes de France. Archives du Museum National d'Histoire Naturelle, ser. 6.11:157-171.

Joyeux, Ch., and J.-G. Baer. 1936. Faune de France 30, Cestodes. Office Central de Faunistique, Paul Lechevalier et Fils, Paris, France. 613 pp.

Kozlov, D. P. 1977. Opredelitel' gel'mintov gryzunov fauny SSSR. Tsestody i trematody. K. M. Ryzhikov, ed. Laboratoriia Gel'mintologii, Akademiia Nauk SSSR. Moskva, U.S.S.R. 275 pp.

Kurtén, B., and E. Anderson. 1980. Pleistocene Mammals of North America. Columbia University Press, New York, New York, U.S.A. 442 pp.

Leuckart, R. 1856. Die Blasenbandwürmer und ihre Entwicklung. J. Ricker'sche Buchhandlung, Giessen, Germany. 162 pp. +3 Taf.

Loos-Frank, B. 1994. Re-description and occurrence of Taenia m. martis (Zeder,1803) Wahl, 1967 in definitive and intermediate hosts of southwestern Germany. Zoologisches Jahrbuch. Systematik 121:137-158.

McGee, S. G. 1980. Helminth parasites of squirrels (Sciuridae) in Saskatchewan. Canadian Journal of Zoology 58:2040-2050.

Pederson, E. D., and P. D. Leiby. 1969. Studies on the biology of Monordotaenia taxidiensis, a taeniid cestode of the badger. Journal of Parasitology 55:759-765.

Pence, D. B., and K. D. Willis. 1978. Helminths of the ringtail, Bassariscus astutus, from west Texas. Journal of Parasitology 64:568-569.
Pfaller, K., and F. Tenora. 1972. Über CestodenLarvenstadien aus Muriden und Microtiden (Rodentia) in Tirol (Österreich). Berichte des naturwissenschaftlichen medizinischen Vereins Innsbruck 59:25-28.

Poole, B. C., K. Chadee, and T. A. Dick. 1983. Helminth parasites of pine marten, Martes americana (Turton), from Manitoba, Canada. Journal of Wildlife Diseases 19:10-13.

Prokopič, J. 1965. Helmintofauna u šelem Československá. Československá parazitologie 12:207-226.

Prokopič, J. 1970. Some notes on the distribution and life history of the cestode Taenia martis (Zeder, 1803). Helminthologia 11:187-193.

Rausch, R. L. 1947. A redescription of Taenia taxidiensis Skinker, 1935. Proceedings of the Helminthological Society of Washington 14:73-75.

Rausch, R. L. 1959. Studies on the helminth fauna of Alaska. XXXVI. Parasites of the wolverine, Gulo gulo L., with observations on the biology of Taenia twitchelli Schwartz, 1924. Journal of Parasitology 45:465-484.

Rausch, R. L. 1977. The specific distinction of Taenia twitchelli Schwartz, 1924 from T. martis (Zeder,1803) (Cestoda:Taeniidae). Pages 357366 in Excerta parasitológica en memoria del Doctor Eduardo Caballero y Caballero. Universidad Nacional Autónoma de México. Instituto de Biología, Publicaciones especiales No. 4. México. 553 pp.

Romanov, I. V. 1952. Novye vidy gel'mintov ot dikikh sobolei. Trudy Gel'mintologicheskoi Laboratorii 4:323-330.

Ryzhikov, K. M., E. V. Gvozdev, M. M. Tokobaev, L. S. Shaldybin, G. V. Matsaberidze, I. V. Merkusheva, E. V. Nadtochii, I. G. Khokhlova, and L. D. Sharpilo. 1978. Opredelitel' gel'mintov gryzunov fauny SSSR. Tsestody i trematody. K. M. Ryzhikov, ed. Laboratoriia Gel'mintologii, Akademiia Nauk SSSR. Nauka, Moskva, U.S.S.R. $174 \mathrm{pp}$.

Schaerer, O. 1987. Die Metacestoden der Kleinsäuger (Insectivora und Rodentia) und ihre Wirtsarten, Verbreitung und Häufigkeit im Kanton Thurgau (Schweiz). Inaugural-Dissertation, Universität Zürich, Zürich, Switzerland. 239 pp.

Schmidt, G. D. 1986. Handbook of Tapeworm Identification. CRC Press, Boca Raton, Florida, U.S.A. $675 \mathrm{pp}$.

Schmidt, R. 1961. Untersuchungen über die Entoparasitenfauna des Magen-Darmtraktes und der Leibeshöhle von Muriden (Rodentia) der Umgebung Halles unter besonderer Berücksichtigung der Cestoden und Nematoden. Wissenschaftliche Zeitschrift der Martin-Luther Universität Halle-Wittenberg, Math.-Nat. 11:457-470.

Shul'ts, R. S., and E. V. Gvozdev. 1970. Osnovy obshchei gel'mintologii. Vol. 1. Morfologiia, sistematika, filogeniia gel'mintov. K. I. Skriabin, ed. Nauka, Moskva, U.S.S.R. 492 pp.

Shuteev, M. M. 1977. Parazitofauna ondatry verkhneobskogo bora. Parazitologiia 11:538-540.

Sprehn, C. 1959. Die Tierwelt Mitteleuropas. Trematoda und Cestoidea. P. Brohmer, P. Ehrmann, und 
G. Ulmer, eds. Verlag von Quelle und Meyer. Leipzig, Germany. 197 pp. + 32 Taf.

Stubbe, M. 1993. Familie Mustelidae Swainson, 1835-Marder. Pages 364-479 in M. Stubbe and F. Krapp, eds. Handbuch der Säugetiere Europas. Band 5/I, Raubsäuger (Teil I). AULA-Verlag, Wiesbaden, Germany. 526 pp.

Thienemann, J. 1906. Untersuchungen über Taenia tenuicollis Rud. mit Berücksichtigung der übrigen Musteliden-Taenien. Inaugural-Dissertation, Universität zu Königsberg i. Pr. Nicolaische Verlags-
Buchhandlung, Berlin, Germany. pp. 5-28 +1 Taf.

Verster, A. 1969. A taxonomic revision of the genus Taenia Linnaeus, 1758 s. str. Onderstepoort Journal of Veterinary Research 36:3-58.

Wahl, E. 1967. Étude parasito-écologique des petits mammifères (Insectivores et Rongeurs) du val de 1'Allondon (Genève). Revue Suisse de Zoologie 74:129-188.

Zeder, J. G. H. 1803. Anleitung zur Naturgeschichte der Eingeweidewürmer. Bamberg, Germany. 432 pp. +4 Taf. 